\title{
The Proposal of Procedure of Lot Size Determination in Production System
}

\author{
VAZAN, P. \& MORAVCIK, O.
}

Abstract: The paper presents the way how to use simulation optimization for determination of lot size in FMS. It provides the basic methods and procedures. The simulation optimization can be alternative procedure to classic analytical methods. This procedure involves more factors that influence lot size, than analytical methods. Therefore it is more accurate.

Key words: Batch production, lot size, simulation, simulation optimization
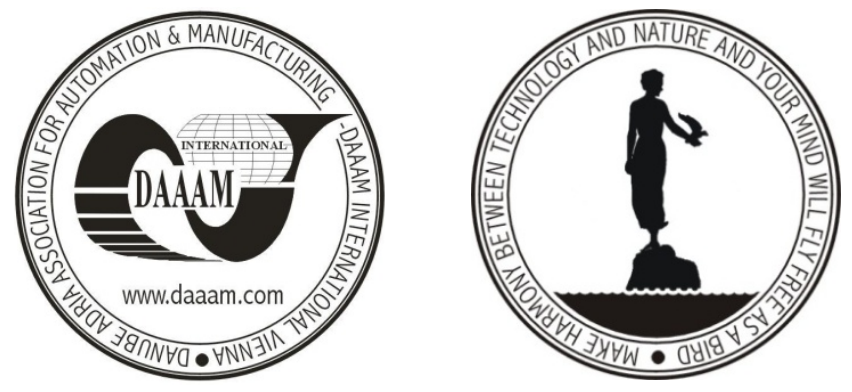

Authors' data: Dr. Doc. Ing. PhD. Vazan, P[avel]*; Prof. Dr. Ing. Moravcik, O[liver]**, *Slovak Universiy of Technology, FMST, Vajanskeho 1, 917 01, Trnava, SK, **Slovak University of Technology, Faculty of Materials, Science and Technology, Budkova 16, SK 81104, Bratislava, SK, pavel.vazan@stuba.sk, oliver.moravcik@stuba.sk

This Publication has to be referred as: Vazan, P[avel] \& Moravcik, O[liver] (2008). The Proposal of Procedure of Lot Size Determination in Production System, Chapter 75 in DAAAM International Scientific Book 2008, pp. 919-926, B. Katalinic (Ed.), Published by DAAAM International, ISBN 978-3-901509-66-7, ISSN 17269687, Vienna, Austria

DOI: $10.2507 /$ daaam.scibook.2008.75 